\title{
Clinical evaluation of root coverage using coronally positioned flap associated with acellular dermal matrix allograft in single-type recession defects. A retrospective study
}

\author{
Guillermo Schinini ${ }^{1,2}$, Alessia Molinari' ${ }^{1}$ Hugo Romanelli' \\ 1. Universidad Maimónides, Carrera de Especialización en Periodoncia, Buenos Aires, Argentina \\ 2. Práctica Privada, Rosario, Argentina
}

\begin{abstract}
The aim of this study was to conduct a retrospective assessment of the clinical results at 6,12 and 24 months of root coverage in single gingival recessions using coronally positioned flap and acellular dermal matrix allograft.

Clinical records were collected from 16 patients with single gingival recessions who visited a private practice in Periodontics in 2005 and 2006. They were treated through a coronally positioned flap and acellular dermal matrix allograft. The following periodontal parameters were recorded at baseline, 6, 12 and 24 months: Recession Depth, Recession Width, Probing Depth, Clinical Attachment Level, Keratinized Tissue Width, Plaque Index, Gingival Index and Sensitivity.

The percentage of root coverage was $91.18 \pm 21.26$ at 6 months, $90.18 \pm 22.04$ at 12 months and $90.83 \pm 18.41$ at 24 months. Complete root coverage was $81 \%$ (13 out of 16) at
\end{abstract}

6 and 12 months. At 24 months, complete root coverage was $75 \%$ (9 out of 12). The plaque and gingival indexes did not vary significantly between baseline and measurement times. Probing depth was maintained at healthy levels during the months of follow-up. Sensitivity decreased at 12 months (4 of 16) compared to baseline (14 of 16), and was maintained at 2 years (2 of 12).

This retrospective study showed that acellular dermal matrix allograft could be considered a useful alternative for the treatment of single gingival recessions, reducing the discomfort and morbidity associated with the palatal donor site.

Received: April 2021; Accepted: June 2021.

Keywords: acellular dermal tissue - alloderm - gingival recession - allografts.

\section{Evaluación clínica del recubrimiento radicular mediante colgajo desplazado coronal asociado a injerto dérmico acelular en recesiones únicas. Estudio retrospectivo}

\begin{abstract}
RESUMEN
El objetivo de este trabajo fue evaluar retrospectivamente los resultados clínicos del recubrimiento radicular en recesiones únicas mediante el uso de colgajo desplazado coronal y matriz dérmica acelular a los 6,12 y 24 meses.

Se recolectaron las historias clínicas de 16 pacientes que presentaban recesiones gingivales únicas, concurrentes a un consultorio privado de Periodoncia en los años 2005 y 2006. Fueron tratados utilizando colgajo desplazado coronal y matriz dérmica acelular. Previamente se registraron los siguientes parámetros periodontales: Altura de la recesión, Ancho de la recesión, Profundidad al sondaje, Nivel Clínico de inserción, Ancho del tejido queratinizado, Indice de placa, Indice gingival y Sensibilidad. Los datos se obtuvieron nuevamente a los 6, 12 y 24 meses.

El porcentaje de recubrimiento radicular obtenido a los 6 meses fue de 91,18 $\pm 21,26$, de 90,18 $\pm 22,04$ a los 12 meses y 90,83 \pm
\end{abstract}

18,41 a los 24 meses. La cobertura radicular completa fue de $81 \%$ (13 de 16) a los 6 y 12 meses, y fue de $75 \%$ a los 24 meses (9 de 12). Los índices de placa y gingival no variaron significativamente entre el inicio y los diferentes intervalos de tiempo. La profundidad al sondaje se mantuvo en niveles compatibles con salud durante los meses de seguimiento. Se logró disminuir la sensibilidad a los 12 meses (4 de 16) respecto al inicio del tratamiento (14 de 16), manteniendo dicha proporción a los 2 años (2 de 12). El presente estudio retrospectivo mostró que el uso de la matriz dérmica acelular podría ser considerado una alternativa predecible para el tratamiento de recesiones gingivales únicas, reduciendo el disconfort y la morbilidad asociada al sitio donante palatino.

Palabras clave: matriz dérmica acelular - alloderm - recesión gingival - injerto. 


\section{INTRODUCTION}

Gingival recession is defined as the apical displacement of the gingival margin with respect to the cementoenamel junction. It is a highly prevalent mucogingival condition worldwide, occurring both in individuals with good and with inadequate oral hygiene ${ }^{1}$. Gingival recession can be localized or involve several teeth, and the ensuing root exposure is associated with an increase in dentin sensitivity, greater susceptibility to root decay, difficulty in removing the biofilm and aesthetic alterations ${ }^{2}$. Recent scientific evidence has shown that untreated gingival recession defects are more likely to progress over time, even with good oral hygiene ${ }^{3,4}$.

Several techniques have been described to achieve root coverage in single gingival recessions, with the connective tissue graft associated with the coronally positioned flap (CPF) being considered the Gold Standard among all possible variants ${ }^{5}$. The ultimate aim of the procedure is to obtain maximum root coverage of the recession treated at the level of the cementoenamel junction, minimum residual probing depth, and excellent gingival camouflage with respect to neighboring tissues without leaving scars or unaesthetic contour and texture alterations in the surrounding tissues.

However, there are certain situations in which it is not always possible to obtain a palatal connective tissue graft, due to the scarce or null amount of donor tissue in the palatal area (little palatal thickness and/or little availability for long grafts, absence of premolar/s in patients with limited opening and flat palate), or when the patient refuses the intervention of a second surgical site that generates greater postoperative morbidity ${ }^{6}$. To solve the problem caused by the limited availability of the graft, there are human or animal substitutes, among them the acellular dermal matrix allograft (ADMA, Alloderm, BioHorizons, Birmingham, AL, USA) which has been used for more than two decades as a substitute for connective tissue in the treatment of gingival recessions, gingival augmentation around teeth and implants and as a barrier in regenerative procedures $^{7,8}$.

This human graft is a non-cellular connective tissue whose cellular content is eliminated through a manufacturer's patented process which preserves the extracellular matrix ultrastructure integrity, allowing the collagen and elastin matrix to be repopulated with new cells and blood vessels without generating an inflammatory response in host tissues ${ }^{9}$. It has a smoother side that does not impregnate with blood (basal lamina) which fosters epithelial migration and a rough side (embedded with the blood of the receptor site), enabling growth of fibroblasts and angiogenic cells. ADMA acts as a non-immunogenic matrix which enables tissue regeneration through cell repopulation and revascularization rather than through a granulation process ${ }^{10}$.

The main advantage in the use of connective tissue graft substitutes is the unlimited availability of donor material, especially useful for the treatment of many teeth or complete arches; and at the same time avoiding the need for a second surgical site, reducing patient morbidity and discomfort in the palatal area.

The objective of this retrospective study is to evaluate the clinical results of root coverage in single gingival recessions using $\mathrm{CPF}$ and $\mathrm{ADMA}$ at 6, 12 and 24 months.

\section{MATERIALS AND METHODS}

The clinical records of patients with single gingival recessions who attended a private practice in Periodontics in 2005 and 2006 were analyzed retrospectively. Sixteen patients (13 female and 3 male) with mean age $32.6 \pm 7.3$ years (range 21-49) were treated. Thirteen were non-smokers, 3 smokers of less than 5 cigarettes per day, all without systemic alterations and showing single gingival recessions (Miller Class I / TR1 Cairo ${ }^{11,12}$ ) in the upper and lower dental arches. The risks and benefits related to the surgical procedure were explained before patients signed the informed consent. The informed consents are preserved in the dental office files. Ten upper canines, 4 upper premolars, 1 upper lateral incisor and one lower premolar with dentin sensitivity and aesthetic alterations were treated.

Scaling and root planing were performed using ultrasonic and manual curettes, and polishing with a non-abrasive paste. A soft brush and interdental aids were indicated together with oral hygiene instructions (Roll Technique). The following parameters were evaluated at baseline, 6, 12 and 24 months: Recession Depth (RD), Recession Width (RW), Probing Depth (PD), Clinical Attachment Level (CAL), Keratinized Tissue Width (KTW), Plaque Index ${ }^{13}$ (PI), Gingival $\operatorname{Index}^{13}$ (GI) and Sensitivity ${ }^{14}$ (SENS). Four patients did not attend the 2-year evaluation. All these measurements were 
performed by the same operator (G.S.) using a PCP UNC-15-millimeter probe (Hu-Friedy®). KTW was measured after topical application of Schiller's iodine solution (Table 1).

After anesthetizing the area, careful scaling and root planning of the exposed root surface and the subgingival portion corresponding to the probing depth of each tooth was performed using 1/2 MiniFive (Hu-Friedy $\left.{ }^{\circledR}\right)$ curettes and ultrasonic devices, without chemical root conditioning (Fig. 1a).

Detailed description of surgical protocol has been published previously ${ }^{15}$. Briefly, intra-sulcular and horizontal incisions extending to the cementoenamel junctions of the adjacent teeth and two oblique releasing incisions exceeding the mucogingival line were made. A partial-full-split thickness flap was raised by sharp dissection.

The anatomical papillae were de-epithelialized using a 15C scalpel and micro-scalpel (Swann Morton ${ }^{\circledR}$ ) (Fig. 1b). ADMA (Alloderm $\AA$, BioHorizons, Birmingham, AL, USA) was used, which was previously immersed in two containers of saline solution for 20 minutes to hydrate it, according to the manufacturer's instructions. The allograft was cut to the shape and size of the sites to be covered and oriented with the rough surface (corresponding

\begin{tabular}{|c|c|c|c|c|c|c|}
\hline Table 1. Preclinical conditions \\
\hline CASE & TOOTH & $\begin{array}{c}\text { PD } \\
\text { (mm) }\end{array}$ & $\begin{array}{c}\text { CAL } \\
\text { (mm) }\end{array}$ & $\begin{array}{c}\text { RD } \\
(\mathbf{m m})\end{array}$ & $\begin{array}{c}\text { RW } \\
(\mathbf{m m})\end{array}$ & $\begin{array}{c}\text { KTW } \\
\mathbf{( m m})\end{array}$ \\
\hline $\mathbf{1}$ & 24 & 2.0 & 5.0 & 3.0 & 3.5 & 3.0 \\
\hline $\mathbf{2}$ & 23 & 1.5 & 6.5 & 5.0 & 5.0 & 1.0 \\
\hline $\mathbf{3}$ & 14 & 1.0 & 4.5 & 3.5 & 4.0 & 2.5 \\
\hline $\mathbf{4}$ & 44 & 1.5 & 4.5 & 3.0 & 3.5 & 2.0 \\
\hline $\mathbf{5}$ & 23 & 2.0 & 4.0 & 2.0 & 4.0 & 3.0 \\
\hline $\mathbf{6}$ & 22 & 1.0 & 3.0 & 2.0 & 3.0 & 2.0 \\
\hline $\mathbf{7}$ & 13 & 0.5 & 4.5 & 4.0 & 4.0 & 1.0 \\
\hline $\mathbf{8}$ & 23 & 1.0 & 4.0 & 3.0 & 5.0 & 2.0 \\
\hline $\mathbf{9}$ & 14 & 2.0 & 4.0 & 2.0 & 3.0 & 3.0 \\
\hline $\mathbf{1 0}$ & 23 & 1.5 & 3.5 & 2.0 & 6.0 & 2.5 \\
\hline $\mathbf{1 1}$ & 13 & 1.0 & 3.0 & 2.0 & 3.5 & 4.0 \\
\hline $\mathbf{1 2}$ & 13 & 1.0 & 4.5 & 3.5 & 4.0 & 3.0 \\
\hline $\mathbf{1 3}$ & 13 & 1.0 & 4.0 & 3.0 & 4.0 & 4.0 \\
\hline $\mathbf{1 4}$ & 23 & 1.5 & 4.5 & 3.0 & 5.0 & 2.0 \\
\hline $\mathbf{1 5}$ & 23 & 1.5 & 4.0 & 2.5 & 3.5 & 3.0 \\
\hline $\mathbf{1 6}$ & 14 & 1.0 & 4.0 & 3.0 & 3.0 & 2.0 \\
\hline $\mathbf{X ( S D )}$ & & $1.3(0.4)$ & $4.2(0.8)$ & $2.9(0.8)$ & $4(0.8)$ & $2.5(0.9)$ \\
\hline PD: Pocket depth; CAL: Clinical attachment level; RD: Recession \\
depth; RW: Recession width; KTW: Keratinized tissue width, X(SD): \\
\hline Mean (Standard Deviation) & & & & \\
\hline & & & & & \\
\hline
\end{tabular}

to the connective side) towards the internal face of the flap, which was finally sutured with 5-0 Chromic Catgut sling suture (Hu-Friedy $\left.{ }^{\circledR}\right)$ at the level of the cementoenamel junction of each tooth (Fig. 1c). Apically, the matrix was extended $3 \mathrm{~mm}$ over the bone. Subsequently, the flap was displaced coronally and sutured beyond the ADMA with Polytetrafluoroethylene suture (PTFE, Cytoplast ${ }^{\circledR}$ $5-0$ ), such that non allograft was left exposed to the oral environment (Fig.1d).

Postoperative Care: Patients were instructed not to brush or floss the area for 3 weeks, and to rinse with $0.12 \%$ chlorhexidine digluconate twice a day until hygiene techniques were resumed. Analgesics were prescribed for a week (Flurbiprofen $100 \mathrm{mg}$ every $12 \mathrm{~h}$ ) and antibiotics for 7 days (Amoxicillin $875 \mathrm{mg}$ every $12 \mathrm{~h}$ ). The sutures were removed 2 weeks after surgery. After a month, mechanical hygiene was resumed using a soft-bristle brush and a sweeping technique (Roll Technique). The healing of the periodontal surgeries proceeded without complications. All parameters were reevaluated at 6, 12 and 24 months (Figs. 1e,1f, 1g).

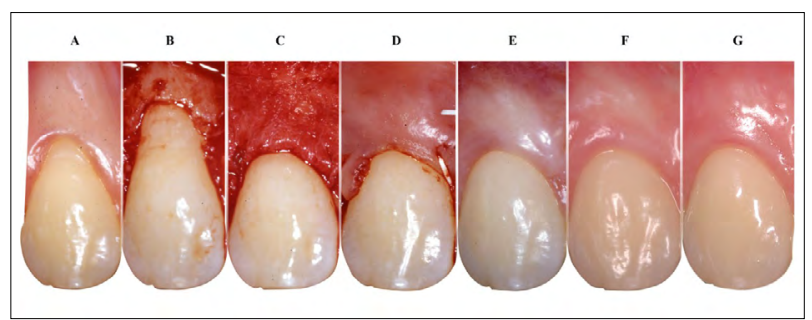

Fig.1: a-Baseline gingival recession. b-Partial/full/partial flap and de-epithelialized papillae. c-Allograft is sutured to the recipient bed. $d$-Coronally positioned flap. e-Postoperative appearance at 6 months. $f$-Postoperative appearance at 1 year. $g$-Postoperative appearance at 2 years.

\section{RESULTS}

PI and GI did not vary significantly between baseline and 24 months. PD was $1.31 \pm 0.44$ at baseline and remained at levels compatible with health during follow-up ( $1.25 \pm 0.40$ at 6 months, $1.18 \pm 0.35$ at 12 months, and $1.29 \pm 0.39$ at 24 months). Considering the average values, the CAL gain at 24 months was $2.7 \mathrm{~mm}$. On the other hand, there was a keratinized gingiva gain of $0.8 \mathrm{~mm}$ between baseline and two years.

$\mathrm{RD}$ decreased from $2.90 \pm 0.84$ (baseline), to 0.28 \pm 0.68 (6 months), $0.31 \pm 0.70$ (12 months) and $0.33 \pm 0.65$ (24 months), obtaining a Root Coverage percentage (\% RC) of $91.18 \%$ at 6 months, $90.18 \%$ 
at 12 months and $90.83 \%$ at 24 months. $81 \%$ was $75 \%$ (9 of 12) (Table 2, Table 3, Fig. 2).

Complete Root Coverage (CRC) was obtained at 6 Individual analysis of cases per year showed that and 12 months (13 of 16). At 24 months, the CRC of the 16 cases evaluated, 13 presented complete

Table 2. Clinical parameters at baseline, 6, 12 and 24 months

\begin{tabular}{|c|c|c|c|c|c|c|c|c|c|c|c|c|c|c|c|}
\hline & 0 & 6 & 12 & 24 & 0 & 6 & 12 & 24 & 0 & 6 & 12 & 24 & 0 & 12 & 24 \\
\hline & \multicolumn{4}{|c|}{$\mathrm{RD}(\mathrm{mm})$} & \multicolumn{4}{|c|}{$\mathrm{RW}(\mathrm{mm})$} & \multicolumn{4}{|c|}{ KTW (mm) } & \multicolumn{3}{|c|}{ SENS (Y/N) } \\
\hline 1 & 3 & 0.5 & 1 & 1 & 3.5 & 1.5 & 2 & 3 & 3 & 3.5 & 3.5 & 3.5 & $Y$ & $\mathrm{~N}$ & $\mathrm{~N}$ \\
\hline 2 & 5 & 0 & 0 & 1 & 5 & 0 & 0 & 3 & 1 & 3 & 2 & 2 & Y & $\mathrm{Y}$ & $\mathrm{Y}$ \\
\hline 3 & 3.5 & 2 & 2 & 2 & 4 & 4 & 4 & 4 & 2.5 & 3 & 3 & 3 & $\mathrm{~N}$ & $\mathrm{Y}$ & $\mathrm{N}$ \\
\hline 4 & 3 & 0 & 0 & 0 & 3.5 & 0 & 0 & 0 & 2 & 3 & 3.5 & 3.5 & $Y$ & $\mathrm{~N}$ & $\mathrm{~N}$ \\
\hline 5 & 2 & 0 & 0 & $\mathrm{~L}$ & 4 & 0 & 0 & $\mathrm{~L}$ & 3 & 4 & 4 & $\mathrm{~L}$ & Y & $\mathrm{N}$ & $\mathrm{L}$ \\
\hline 6 & 2 & 0 & 0 & 0 & 3 & 0 & 0 & 0 & 2 & 4 & 4 & 4 & Y & $N$ & $\mathrm{~N}$ \\
\hline 7 & 4 & 0 & 0 & 0 & 4 & 0 & 0 & 0 & 1 & 3 & 3 & 3 & $Y$ & $N$ & $\mathrm{~N}$ \\
\hline 8 & 3 & 0 & 0 & 0 & 5 & 0 & 0 & 0 & 2 & 2 & 2 & 2 & $Y$ & $\mathrm{~N}$ & $\mathrm{~N}$ \\
\hline 9 & 2 & 0 & 0 & $\mathrm{~L}$ & 3 & 0 & 0 & $\mathrm{~L}$ & 3 & 4 & 4 & L & $Y$ & $N$ & $\mathrm{~L}$ \\
\hline 10 & 2 & 0 & 0 & 0 & 6 & 0 & 0 & 0 & 2.5 & 3.5 & 3 & 3 & $Y$ & $\mathrm{~N}$ & $\mathrm{~N}$ \\
\hline 11 & 2 & 0 & 0 & 0 & 3.5 & 0 & 0 & 0 & 4 & 5 & 5 & 5 & $Y$ & $\mathrm{~N}$ & $\mathrm{~N}$ \\
\hline 12 & 3.5 & 0 & 0 & 0 & 4 & 0 & 0 & 0 & 3 & 3 & 3 & 3 & $Y$ & $\mathrm{~N}$ & $\mathrm{~N}$ \\
\hline 13 & 3 & 0 & 0 & $\mathrm{~L}$ & 4 & 0 & 0 & $\mathrm{~L}$ & 4 & 4 & 5 & L & $Y$ & $Y$ & $\mathrm{~L}$ \\
\hline 14 & 3 & 2 & 2 & $\mathrm{~L}$ & 5 & 4 & 4 & $\mathrm{~L}$ & 2 & 3 & 3 & L & $\mathrm{N}$ & $\mathrm{N}$ & $\mathrm{L}$ \\
\hline 15 & 2.5 & 0 & 0 & 0 & 3.5 & 0 & 0 & 0 & 3 & 4 & 4 & 4 & $Y$ & $N$ & $\mathrm{~N}$ \\
\hline 16 & 3 & 0 & 0 & 0 & 3 & 0 & 0 & 0 & 2 & 3.5 & 4 & 4 & $Y$ & $Y$ & $Y$ \\
\hline
\end{tabular}

RD: Recession depth; RW: Recession width; KTW: Keratinized tissue width; SENS: sensitivity; Y: Yes; N: No; L: lost to follow up

\section{Table 3. Mean root coverage and complete root} coverage at 6, 12 and 24 months

\begin{tabular}{|l|l|l|l|l|l|l} 
MONTH & 6 & 12 & 24 & 6 & 12 & 24 \\
\hline
\end{tabular}

\begin{tabular}{|c|c|c|c|c|c|c|c|c|}
\hline & \# TOOTH & \multicolumn{3}{|c|}{ RC (\%) } & \multicolumn{3}{|c}{ CRC (Y/N) } \\
\hline 1 & 24 & 83 & 67 & 67 & N & N & N \\
\hline 2 & 23 & 100 & 100 & 80 & Y & Y & N \\
\hline 3 & 14 & 43 & 43 & 43 & N & N & N \\
\hline 4 & 44 & 100 & 100 & 100 & Y & Y & Y \\
\hline 5 & 23 & 100 & 100 & L & Y & Y & L \\
\hline 6 & 22 & 100 & 100 & 100 & Y & Y & Y \\
\hline 7 & 13 & 100 & 100 & 100 & Y & Y & Y \\
\hline 8 & 23 & 100 & 100 & 100 & Y & Y & Y \\
\hline 9 & 14 & 100 & 100 & L & Y & Y & L \\
\hline 10 & 23 & 100 & 100 & 100 & Y & Y & Y \\
\hline 11 & 13 & 100 & 100 & 100 & Y & Y & Y \\
\hline 12 & 13 & 100 & 100 & 100 & Y & Y & Y \\
\hline 13 & 13 & 100 & 100 & L & Y & Y & L \\
\hline 14 & 23 & 33 & 33 & L & N & N & L \\
\hline 15 & 23 & 100 & 100 & 100 & Y & Y & Y \\
\hline 16 & 14 & 100 & 100 & 100 & Y & Y & Y \\
\hline & M\% & 91 & 81 & 91 & 81 & 81 & 75 \\
\hline
\end{tabular}

RC: Root Coverage; CRC: Complete Root Coverage; L: Lost to follow-up; Y: Yes; N: No; M\%: Mean percentage

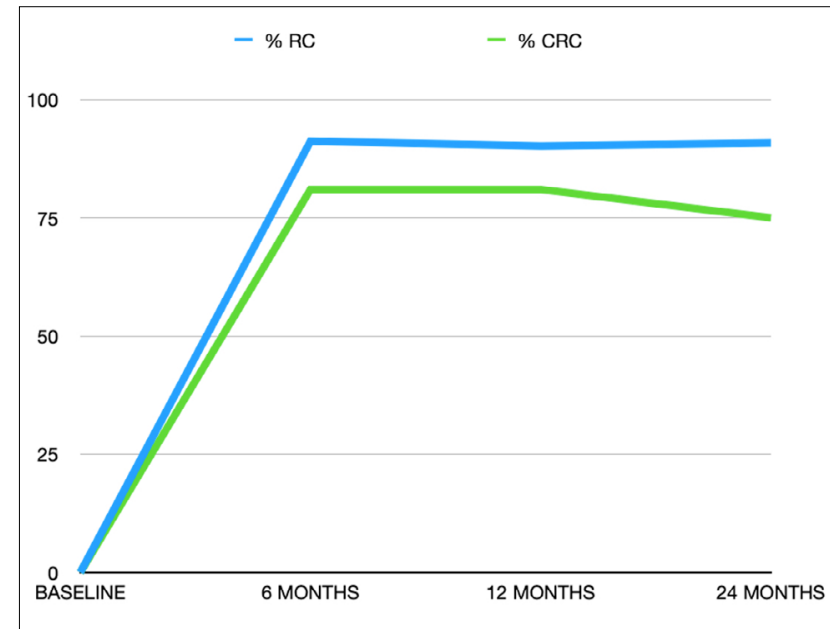

Fig. 2: Mean Root Coverage (\% RC) and Complete Root Coverage (CRC) at 6, 12 and 24 months.

coverage of the gingival recession $(81 \%$ of the sites). Of those that did not have $\mathrm{CRC}$, one case had $86 \% \mathrm{RC}$ and 2 cases obtained $43 \%$ and $33 \%$ $\mathrm{RC}$, respectively. At 24 months, of the 12 cases that had achieved $100 \% \mathrm{RC}, 8$ remained stable, $3 \mathrm{did}$ not attend the follow-up visit and one presented a mild gingival recession relapse $(85 \% \mathrm{RC})$. Of the 
cases that did not achieve full coverage at one year, one did not attend the follow-up visits and the other two maintained the level of the gingival recession within the parameters reached in the first year. Sensitivity (SENS) was reduced at 12 months (4 of 16) compared to the start of treatment (14 of 16) and remained stable at 24 months ( 2 of 12).

\section{DISCUSSION}

ADMA has been considered a valid alternative to subepithelial connective tissue in different periodontal plastic surgery procedures. It has some advantages over other surgical procedures for the treatment of single and multiple gingival recessions. It does not require a second donor site, it allows for an unlimited amount of the material, as well as suitable camouflage with respect to the color and texture of the neighboring soft tissues. In turn, the material can be positioned and sutured on the receptor bed either on the connective side or the basement membrane side, without affecting the results of the treatment ${ }^{16}$. The use of ADMA associated with CPF has shown successful results in the treatment of single gingival recessions (Miller Class I and II / Cairo RT1), showing a high percentage of root coverage ranging from $70 \%$ to $95 \%$, and a short-term increase in gingival thickness of $0.5 \mathrm{~mm}$ to $0.7 \mathrm{~mm}^{17-22}$. The increase in gingival thickness is considered an important factor to avoid recurrence of the lesion, since increasing the gingival phenotype counteracts the negative influence of traumatic brushing.

Based on short-term studies, the current study agrees with different publications in the literature in terms of gingival recession reduction, percentage of root coverage and increase of keratinized gingiva ${ }^{18,20}$. Our study achieved $91.19 \%$ root coverage at 6 months, $90.19 \%$ at 12 months, and $90.83 \%$ at 24 months. In addition, the percentage of complete root coverage was $81 \%$ at 6 months, remaining unchanged at one year. At 2 years, the CRC was reduced to $75 \%$. Nowadays, the clinical evaluation of CRC must be accompanied by an aesthetic evaluation, i.e., achieving stable levels in the long term of gingival margins at the level of the cementoenamel junction as well as adequate texture, color and tissue contour ${ }^{23}$. The increase in KTW was $0.8 \mathrm{~mm}$ at 2 years. Other authors reported an increase in keratinized tissue between $0.4 \mathrm{~mm}$ and $1.2 \mathrm{~mm}$ at 12 months ${ }^{19,20,22,24}$. However, the cellular dynamics and keratinization process during healing using ADMA is not fully understood and its behavior as an inducer of keratinization needs further research ${ }^{25}$.

Miller identified certain success criteria for root coverage procedures. Among them, he mentioned that the depth of the sulcus should be $2 \mathrm{~mm}$ or less without bleeding on probing ${ }^{26}$. At the beginning, the PD measurements were consistent with health and remained unchanged during the evaluated healing intervals. Similarly, PI and GI remained at low levels during the 24 months.

Dentin hypersensitivity is a frequent finding in patients with gingival recessions, with root coverage procedures being an alternative for its treatment. In this report, sensitivity was reduced from $87 \%$ before treatment (14 of 16 ) to $25 \%$ at one year ( 4 of 16 ) and $17 \%$ at 2 years (2 of 12$)$. The presence of said postoperative residual sensitivity could be explained by the lack of CRC in $100 \%$ of the individuals at different times.

Several published studies related to single gingival recession coverage using ADMA and CPF provide short-term evaluation ( $\leq 12$ months), and there is limited evidence with follow-up longer than 2 years. Harris reported a case series on 20 patients treated with ADMA and found that average root coverage was $91 \%$ at 3 months and $87 \%$ at 18 months $^{18}$. In a short- and long-term retrospective study, Harris found that average root coverage was $93 \%$ at 3 months, decreasing to $70 \%$ at 48 months for multiple gingival recessions treated with ADMA and $50 \%$ in single gingival recessions ${ }^{27}$. These results suggest a worsening in long-term compared to short-term results. However, this author states that in $32 \%$ of the cases treated by ADMA and CPF, the results improved or remained stable over time.

In the current retrospective study, 3 out of 16 cases did not obtain CRC at 1 year; 2 of them were smokers, while the case that obtained the lowest percentage of root coverage ( $43 \%$ ), corresponds to a non-smoker who inflicted toothbrush-trauma during the initial healing phase. At a 24-month evaluation of these 3 cases, 1 had dropped out of the study and in the other two, the gingival margin level reached at 12 months remained stable. Of the 13 cases that had achieved $100 \% \mathrm{RC}$ at 1 year, 9 remained stable, 3 did not attend the follow-up visit and only one had a slight increase in gingival recession at the 24-month evaluation.

Although there is variability in the results obtained with the use of ADMA associated with the CPF for 
the treatment of single gingival recessions, its use can be considered a valid alternative to connective tissue graft, due to the decrease in morbidity and discomfort, fewer complications and work-time in situ, unlimited availability of graft material and the possibility of full-arch treatments in the same session $^{28}$.

Due to the limitations of this study, the results should be considered with caution, since randomized controlled studies with a long-term follow-up period are needed to assess the stability of the outcomes reported herein.

\section{ACKNOWLEDGMENTS}

We thank Dr. Mariel V. Gomez for reviewing the manuscript.

\section{DECLARATION OF CONFLICTING INTERESTS}

The authors declare no potential conflicts of interest regarding the research, authorship, and/or publication of this article.

\section{CONCLUSION}

The percentage of root coverage obtained was slightly higher than $90 \%$ and remained stable throughout the evaluation period. Complete root coverage was achieved in $81 \%$ of the cases at 6 and 12 months and $75 \%$ at 24 months. Acellular dermal matrix allograft is considered a useful alternative to the treatment of single and multiple gingival recessions, reducing discomfort and morbidity associated with the palatal donor site.

\section{FUNDING}

None

\section{CORRESPONDENCE}

Dr Guillermo Schinini

Rioja 2625, 2000 Rosario

Pcia. Santa Fe, Argentina

guillermo.schinini@gmail.com

\section{REFERENCES}

1. Ishikawa I, McGuire M, Mealey B, Blieden $\mathrm{T}$ et al. Consensus Report: Mucogingival deformities and conditions around teeth. Ann Periodontol 1999;4:101.

2. Merijohn G. Management and prevention of gingival recession. Periodontology 2000, 2016;71:228-242.

3. Chambrone L, Tatakis DN. Long-term outcomes of untreated buccal gingival recessions. A systematic review and meta-analysis. J Periodontol 2016;87:796-808.

4. Agudio G, Cortellini P, Buti J, Pini Prato GP. Periodontal conditions of sites treated with gingival augmentation surgery compared with untreated contralateral homologous sites: An 18 to 35 year Long term study. J Periodontol 2016;87:1371-1378.

5. Chambrone L, Lima L, Pustiglioni F, Chambrone L. Systematic review of periodontal plastic surgery in the treatment of multiple recession-type defects. J Can Dent Assoc 2009,75:203a-f.

6. Chambrone L, Tatakis DN. Periodontal soft tissue root coverage procedures: a systematic review from the AAP Regeneration Workshop. J Periodontol 2015;86 (2 Suppl):S8-51. doi: 10.1902/jop.2015.130674.

7. Andrade P, Souza S, Macedo G, Novaes AB et al. Acellular dermal matrix as a membrane for guided tissue regeneration in the treatment of class II furcation lesions. J Periodontol 2007,78:1288-1299.

8. Borges G, Novaes AB, Grisi M, Palioto D et al. Acellular dermal matrix as a barrier in guided bone regeneration: a clinical, radiographic and histomorphometric study in dogs. Clin Oral Impl Res 2009;20:1105-1115.

9. Bohac M, Danisovic L, Koller J, Dragunova J et al. What happens to an acellular dermal matrix after implantation in the human body? A histological and electron microscopic study. Eur J Histochem 2018;62:2873.

10. Cummings L, Kaldahl W, Allen EP. Histologic evaluation of autogenous connective tissue and acellular dermal matrix grafts in humans. J Periodontol 2005;76:178-186.

11. Miller PD Jr. A classification of marginal tissue recession. Int J Periodontics Restorative Dent 1985;5:8-13.

12. Cairo F, Nieri M, Cincinelli S, Mervelt J, Pagliaro U. The interproximal clinical attachment level to classify gingival recessions and predict root coverage outcomes: an explorative and reliability study. J Clin Periodontol 2011; 38:661-666.

13. Löe, H. The Gingival Index, the Plaque Index and the Retention Index Systems. J Periodontol 1967; 38; Suppl:610-6.

14. Yates RJ, Newcombe RG, Addy M. Dentine hypersensitivity: a randomized, double blind placebo-controlled study of the efficacy of a fluoride-sensitive teeth mouthrinse. J Clin Periodontol 2004; 31: 885-889.

15. de Sanctis M, Zucchelli G.Coronally advanced flap: a modified surgical approach for isolated recession-type defects: three-year results. J Clin Periodontol. 2007; 34:262268.

16. Henderson RD, Greenwell H, Drisko C, Regennitter FJ et al. Predictable multiple site root coverage using an acellular dermal matrix allograft. J Periodontol 2001;72:571-582.

17. Harris R. A comparison of root coverage obtained with a connective tissue graft versus an acellular dermal matrix. J Periodontol 1999; 70: 235.

18. Harris R. Acellular dermal matrix used for root coverage: 18-month follow-up observation. Int $\mathrm{J}$ Periodontics Restorative Dent 2002; 22:156-163.

19. Moslemi N, Jazi MM, Haghighati F, Morovati SP et al. 
Acellular dermal matrix allograft versus subepithelial connective tissue graft in treatment of gingival recessions: a 5-year randomized clinical study. J Clin Periodontol 2011; 38:1122-1129.

20. Santos A, Goumenos G, Pascual A. Management of gingival Recession by the use of an Acellular Dermal graft Material: A 12 Case Series. J Periodontol 2005;76:1982-1990.

21. Felipe ME, Andrade PF, Grisi MF, Souza SL et al. Comparison of two surgical procedures for use of the acellular dermal matrix graft in the treatment of gingival recessions: a randomized controlled clinical study. J Periodontol.2007;78:1209-1217.

22. De Queiroz Cortes A, Sallum AW, Casati MZ, Nociti FH Jr et al. A two-year prospective study of coronally positioned flap with or without acellular dermal matrix graft. J Clin Periodontol 2006; 33: 683-689.

23. Cairo F, Rotundo R, Miller PD, Pini Prato GP. Root coverage esthetic score: A system to evaluate the esthetic outcome of the treatment of gingival recession through evaluation of clinical cases. J Periodontol 2009;80:705-710.

24. Andrade PF, Felipe ME, Novaes AB Jr, Souza SL et al. Comparison between two surgical techniques for root coverage with an acellular dermal matrix graft. J Clin Periodontol. 2008;35:263-269.

25. Novaes AB Jr, Grisi DC, Molina GO, Souza SL et al. Comparative 6-month clinical study of a subepithelial connective tissue graft and acellular dermal matrix graft for the treatment of gingival recession.J Periodontol. 2001;72:1477-1484.

26. Miller PD Jr. Root coverage with the free gingival graft. Factors associated with incomplete coverage. J Periodontol 1987; 58:674-681.

27. Harris RJ. A short-term and long-term comparison of root coverage with an acellular dermal matrix and a subepithelial graft. J Periodontol. 2004 May;75:734-743.

28. Gapski R, Parks CA, Wang HL. Acellular dermal matrix for mucogingival surgery: a meta-analysis. J Periodontol 2005;76:1814-1822. 